\title{
GEOLOGICAL AND GEOPHYSICAL DATA OF “EPSILON” FIELD IN PRINOS OIL BASIN
}

\author{
Mertzanides Y. ${ }^{1}$, Kargiotis E. ${ }^{1}$, Mitropoulos A. ${ }^{1}$ \\ ${ }^{1}$ Department of Oil and Gas Technology, Technological Educational Institute of Kavala,65404, \\ Kavala-Greece,mertzan@gmail.com
}

\begin{abstract}
The Epsilon field, is located at the centre of Prinos oil basin (N. Aegean, Greece), $11 \mathrm{~km} N W$ of the island of Thassos and $4 \mathrm{~km} \mathrm{NW}$ of the Prinos field, the first productive oil field in the Aegean Sea. The taphrogenetic basin of Prinos has been widely studied, due to its hydrocarbon reservoirs. Extensive geophysical survey, started at early 1970 's, led to a number of drilling jobs, which confirmed the existence of hydrocarbons in the area. The combined geological information, derived from the analysis of lithological, stratigraphic and geochemical data of the basin, suggested a structural and depositional model, strongly related to the Miocene tectonics and sedimentation. The new geophysical and drilling data from Epsilon oil field, are correlated to that already known, completing the model of the basin. Pay zone is found to be below an evaporitic sequence, consisting predominantly of salt, with anhydrite, clay and sandstone intercalations. These upper Miocene aged evaporites extend, varying in thickness, throughout Prinos basin. Reservoir consists mainly of sandstone with intercalations of claystone and trace of siltstone. The geology of the structure and the initial productivity, were positive for further drilling operations in Epsilon field.
\end{abstract}

Key words: Prinos taphrogenetic basin, anticline, evaporites, Epsilon oil field, drilling data.

\section{Introduction}

The Epsilon oil field is located in the north Aegean Sea between the Greek mainland and the island of Thassos, approximately $11 \mathrm{~km} \mathrm{S-SE}$ of the city of Kavala. It belongs to the taphrogenetic basin of Prinos, the only area with productive hydrocarbon fields in Greece (Fig. 1). Geophysical (seismic) exploration in the area at large, started in 1970 and resulted to a number of drillings. The first well was drilled in 1971, $20 \mathrm{~km}$ east of Thassos island but encountered very low gravity oil (Proedrou and Sidiropoulos, 1992). In 1972-1973 the next two wells were drilled west of the island and led to the discovery of South Kavala gas field in $52 \mathrm{~m}$ of water depth. The main reservoir was a tourbiditic sand package, contained in between a sequence of evaporites. It consisted mainly of methan and small quantities of ethan, propan and butan (Proedrou and Sidiropoulos, 1992; Proedrou, 2001). The fourth drilling attempt, was at the end of 1973, at the centre of Prinos basin and led to the discovery of Prinos oil field in a water depth of approximately $30 \mathrm{~m}$. The oil was present in stacked turbiditic sandstones, in four reservoir units. It was waxy, containing a high proportion of asphaltenes, sulphur and $\mathrm{H}_{2} \mathrm{~S}$ (Proedrou and Sidiropoulos, 1992). Four delineation wells in 19751977 (Proedrou and Sidiropoulos, 1992) and a 3-D seismic survey followed by interpretation in 1993-1995, confirmed the presence of North Prinos oil field. The five wells that were drilled in 1976, 1994, 1996, 2004 and 2009, kept the field in production till today. 
The Epsilon oil field was discovered in late 2000, in a water depth of 30-40 m. The well E-1 drilled in 2001 but it was suspended and re-entered in 2002 as E-1A. Technical problems led to re-drilling in 2002 and the well was sidetracked as E-1As.

This work presents geological and geophysical data from Epsilon oil field in Prinos basin. Data were given from KAVALA OIL SA, as part of the project ARCHIMEDES II: "Rock 'n' oil-The Kavala band", supervised by Department of Oil and Gas Technology, Technological Educational Institute of Kavala. The project was co-financed by the European Social Fund (75\%) and Greek national resources (25\%), under the Framework of the Third Community Support Framework 2000-2006, Operational Program for Education and Initial Vocational Training, Priority Action Line 2 - Promotional Improvement of Education and Vocational Training within the framework of Lifelong Training, Measure 2.2 - Reformation of Studies Programmes, Expansion of Higher Education, Action 2.2.3 - Postgraduate Studies Courses, Research Scholarships, Action Category 7 - Enhancement of Research Groups in Technological Educational Institutes.

\section{Prinos basin model}

\subsection{Geotectonic evolution}

The extensive exploration for hydrocarbons in the offshore area at large of Thassos island and the study of the well drilling data that followed on, since 1970, brought the information for understanding the geotectonic evolution of the area. A detailed description of this information and a complete model for the geology and the depositional model of Prinos basin can be found in literature (Pollak, 1979; Proedrou, 1979; 1988; Proedrou and Sidiropoulos, 1992; Georgakopoulos, 1998; 2000; Proedrou, 2001; Proedrou and Papaconstantinou, 2004; Kiomourtzi, 2007; 2008; 2009). According to this model, the Prinos basin is a result of the post-alpine tectonism that started in early to middle Miocene and led to the breaking of the Aegean plate and to the subsidence of the pre-alpine Rhodope massiv under the sea level. This gravity tectonics was responsible for the genesis of grabens and horsts in North Aegean. A number of gravity, often echelon, faults with NE-SW and NW-SE direction formed the taphrogenetic basin of Prinos. Its length is approximately $38 \mathrm{~km}$, from Nestos river delta in NE, to offshore south Kavala ridge in SW. Its width is approximately $20 \mathrm{~km}$, from Thassos island in SE, to the opposite mainland in NW. It is subdivided into two sub-basins, separated by a topographic basement high, in Ammodhis area (Fig. 1). The Nestos sub-basin is located at the north part and the Prinos sub-basin, deeper than the previous, at the south part. The taphrogenetic basin is structured by roll-over anticlines, formed by NW-striking and SW-dipping faults which are related to the trapping mechanism (Fig. 2). These faults, still active today, activated during sedimentation (syngenetic faults) and resulted in the dome-like anticlines of Prinos, North Prinos, Epsilon, Ammodhis and South Kavala (Fig. 1).

The NE part of Prinos basin was probable close by the first time of its formation, while the SW basement started to uplift by messinian period, forming the south Kavala ridge (Fig. 1). The basin was gradually isolated from the open sea and changed into a lagoon.

\subsection{Stratigraphy}

The stratigraphy model of the taphrogenetic basin has been presented by Pollak (1979) and Proedrou (1979) (Fig. 3). According to this, the generalized stratigraphic column is divided into three series:

- The Pre-Evaporitic Series.

- The Evaporitic Series.

- The Post-Evaporitic Series. 


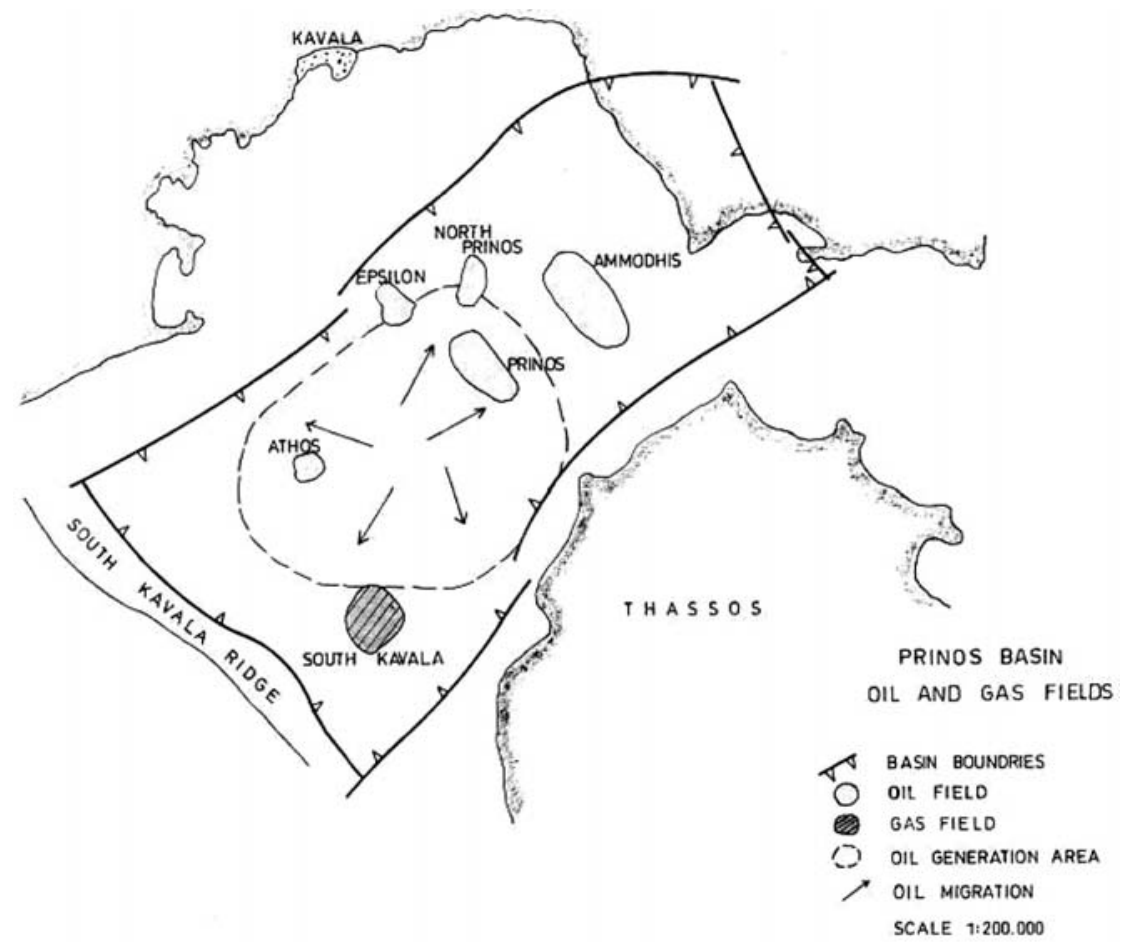

Fig. 1: The Epsilon oil field is located in the middle and north part of the basin of Prinos (N. Aegean Sea). Along with Prinos field, Prinos North field and South Kavala gas filed are the only productive hydrocarbon fields in Greece. The oil generation and the migration paths are shown. Figure from Proedrou and Papaconstantinou (2004).

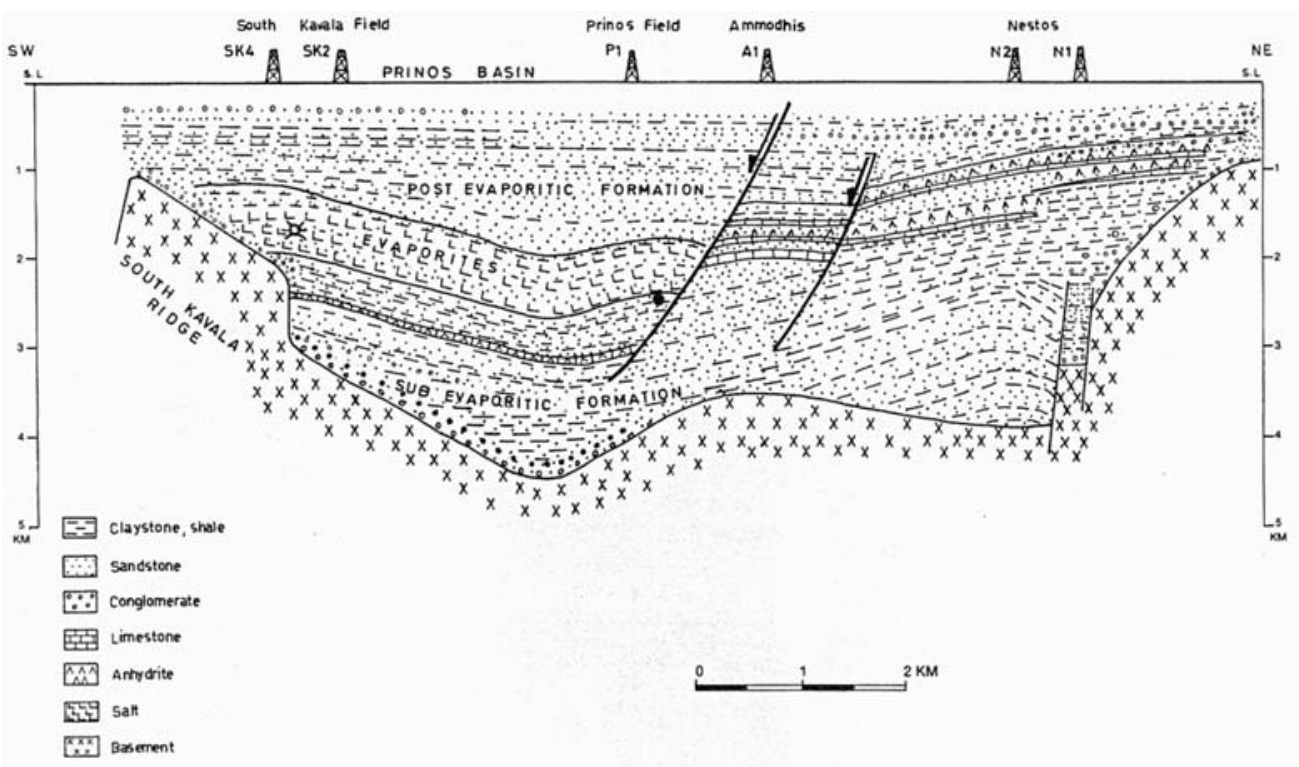

Fig. 2: Simplified cross section of the Prinos basin parallel to the long axis. The roll-over syngenetic faulting formed the dome-like anticlines. Depths in kilometres below mean sea level. Figure from Proedrou and Sidiropoulos (1992). 


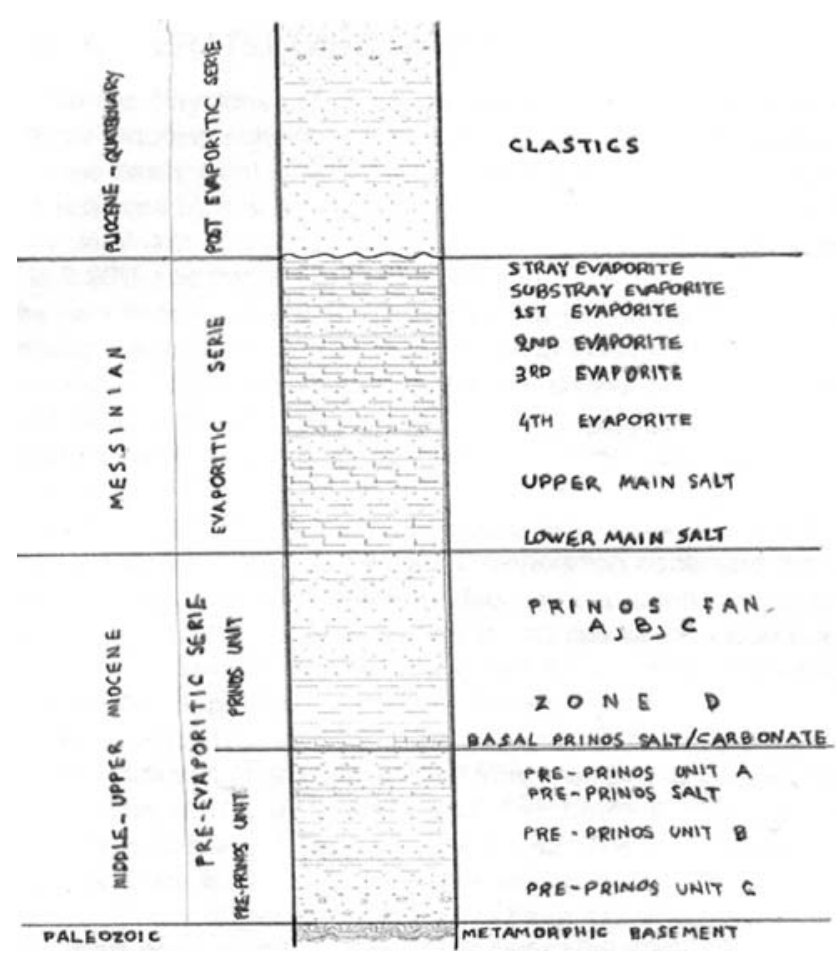

Fig. 3: Generalized chronostratigraphic column of Prinos basin. Figure from Proedrou and Sidiropoulos (2004).

The Palaeozoic basement is composed of metamorphic rocks: gneiss, quartzite and dolomitic marble. The Pre-Evaporitic Series, closely related to Miocene tectonics, begins with continental deposits: conglomerates with large basement components, sandstones, feldspatic, mainly immature, claystones and thick coal seems. These continental deposits originated from the NE and SW parts of the basin, decrease in thickness towards the centre of the sub-basins. They are followed by marine deposits of shales with interbedded sandstones, coarser at the periphery of the basin, which overlay the older ones with an unconformity. Above these units, a zone of limestone, dolomite and anhydrite layers alternated with clastics follows. Towards the centre of the basin, to the deeper parts, the anhydrite is replaced by a few metres thick layers of salt. At the top of the Pre-Evaporitic Series, at Prinos sub-basin, there is an extended deposition of dark gray claystone, the zone D. It is petroliferous and strong carbonaceous, with sandstone intercalations. The following Prinos sub-marine fan, consists entirely of turbiditic fan deposits, which were deposited along the downthrown side of a fault escarpment. The present facies, are representative of the turbidite facies classification of Walker and Mutti (1973). At Nestos sub-basin, the equivalent zone is the pro-deltaic varves (Proedrou and Papaconstantinou, 2004).

The Evaporitic Series, closely related to Messinian "Salinity Crisis" of the Mediterranean Sea (Hsu, 1972), consists of two facies, in each of the two sub-basins. In the northern one, anhydrite and limestone layers 3-5 m thick, alternate each other and with sandstone, claystones and marls, too. The series in the southern part, consists of 7-8 salt layers with increasing thickness towards the base of the section, which alternate with clastics and has a total thickness up to $800 \mathrm{~m}$. The salt is white, gray, crystalline, often intercalated by anhydrite and dolomite layers (Proedrou and Papaconstantinou, 2004). 


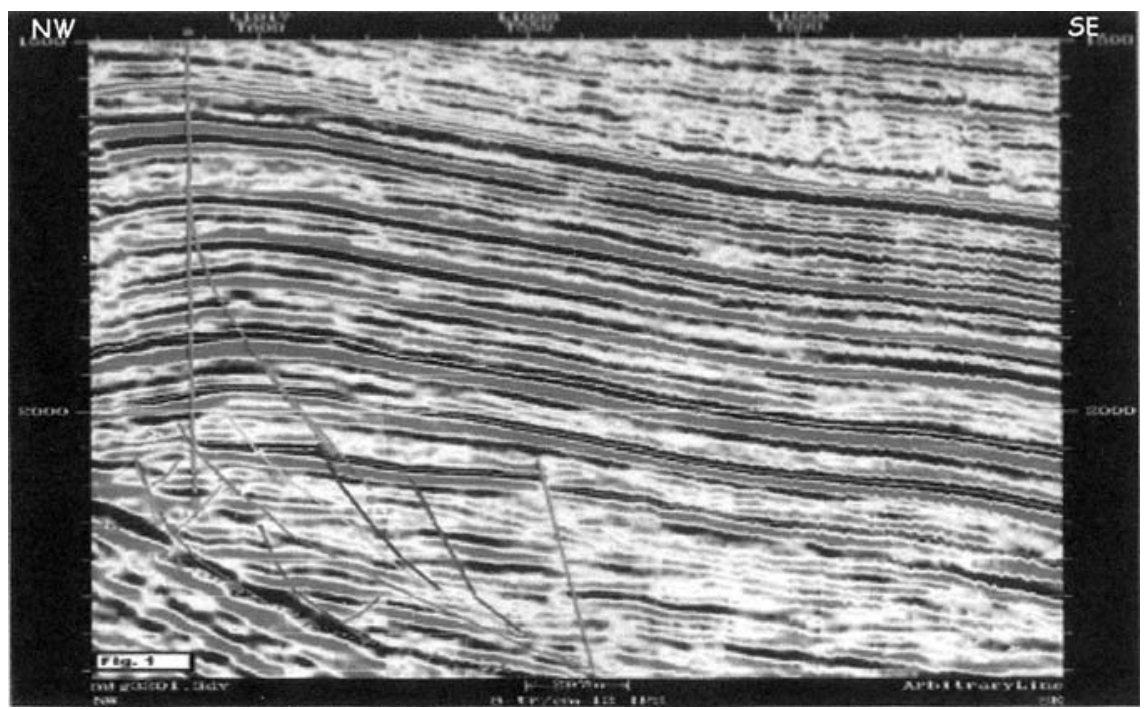

Fig. 4: NW-SE seismic section across the wells E-1 and E-1As in Epsilon oil field of Prinos basin. The anticlinal structure with the downthrown faults are well illustrated from the seismic reflectors.

The Post-Evaporitic Series is pure clastic and marine origin, as indicated by the presence of a great number of Pliocene foraminifere and algae. Towards the top, coarse clastic sediments with abundant rests of molluscs point out to a deltaic, according the seismic, prograding sequence. A transgression followed with deposition of marine clastic sediments (Proedrou and Papaconstantinou, 2004).

These three series reflect the different sedimentological conditions of each period and generally, increase in thickness towards the centre of the sub-basins.

\subsection{Reservoirs}

Hydrocarbon fields in Prinos basin are related to rollover anticlines, which are in front of syngenetic NW-SE striking downthrown faults or surrounded by downthrown faults. Prinos oil field, Prinos North oil field and South Kavala gas field belong to the former and Ammodhis and Epsilon fields to the latter case (Proedrou and Papaconstantinou, 2004).

Reservoirs are mainly sandstones and secondly siltstones, that resulted of the uppermost Miocene depositions from deltaic, marine and turbiditic environments. The evaporites cover the whole basin, keeping hydrocarbons below them, except from an upward movement of hydrocarbons in South Kavala and Ammodhis fields, probable due to fault activation. Generally, porosity and permeability is decreasing with increasing depth, due to weight overlay, clay content and dolomitization (Proedrou and Papaconstantinou, 2004).

\section{Epsilon field data}

\subsection{Seismic section}

The Epsilon oil field is located in the middle of the Prinos basin axis, close to the north slope of the basin, approximately $4.2 \mathrm{~km} \mathrm{W-NW}$ of the Prinos oil field (Fig. 1). The 3-D seismic survey that took place the period 1993-1997, indicated the existence of a new hydrocarbon field in the area. 
The first well, E-1, was drilled in 2001 and confirmed the results of the geophysical research, but as mentioned in section 1, technical reasons dictated the redrilling in 2002, originally with E-1A and finally with E-1As wells.

The discovery of Epsilon oil field brought some new data for the already well studied Prinos basin. In Fig. 4, the NW-SE seismic section across the wells E-1 and E-1As is shown. The anticlinal structure of Epsilon field with the downthrown faults are well illustrated from the seismic reflectors.

\subsection{Drilling data}

According to the E-1 well drilling data, as recorded by KAVALA OIL S.A., the Evaporitic Series started at $1895 \mathrm{~m}$ (all depths T.V.D.). The $40 \mathrm{~m}$ thick stray evaporite zone consisted predominantly of anhydrite and salt with claystone, limestone and sandstone. The $1^{\text {st }}$ evaporite horizon was found at $2096 \mathrm{~m}$ depth. It consisted of salt and traces of anhydrite. The salt was colourless, white or milky white, translucent, firm or crystalline. The anhydrite was white, soft to moderately firm, cryptocrystalline and occasionally microstystalline. The thickness of the horizon was about $34 \mathrm{~m}$. The $2^{\text {nd }}$ evaporite horizon was found at $2195 \mathrm{~m}$ depth in well E-1 and at $2195.5 \mathrm{~m}$ depth in well E-1A (KOP from well E-1 was at $2135 \mathrm{~m}$ ). It consisted of salt with anhydrite intercalations and had a thickness of about $50 \mathrm{~m}$. The salt was again colourless, white, tan, transparent, firm, well crystalline, occasionally with succrosic texture and anhydritic. The anhydrite again it was white, soft to moderately firm, cryptocrystalline and occasionally microstystalline. There were also traces of gray, soft plastic and soluble clay. The $3^{\text {rd }}$ evaporite horizon was found at depths of $2321.5 \mathrm{~m}$ in well E- 1 and $2319 \mathrm{~m}$ in well E-1A. It was composed of salt with clay and sandstone intercalations. The salt was similar to the $1^{\text {st }}$ and $2^{\text {nd }}$ evaporite, except that sometimes it was anhydritic with up to $10 \%$ anhydrite with traces of gypsum. The claystone was gray, soft, highly washable and calcareous. The thickness of this horizon was 30-34 m. The $4^{\text {th }}$ evaporite was met at depths of $2483.5 \mathrm{~m}$ in well E1, $2476.5 \mathrm{~m}$ in well E-1A and $2479.5 \mathrm{~m}$ in well E-1As. It consisted of salt and anhydrite, up to $10 \%$. The salt was colourless, white to off white, milky white, soft to firm, with succrosic texture, crumby, well crystalline and occasionally microcrystalline. The anhydrite was milky white, soft to moderately firm, pasted and occasionally cryptocrystalline. The thickness of this series was 46-50 m.

The Upper Main Salt (UMS) zone was found at $2633 \mathrm{~m}$ deep in E-1 well, while in wells E-1A and E-1As at $2630 \mathrm{~m}$ deep and had a thickness of 50-57 m. The Lower Main Salt (LMS) was at depths of $2769 \mathrm{~m}, 2775.5 \mathrm{~m}$ and $2777 \mathrm{~m}$ at wells E-1, E-1A and E-1As, correspondingly and had a thickness of 30-42.5 m. Both UMS and LMS zones were becoming thicker from the NW to the SE, towards E-1As well.

The cap rock (claystone 70-90\% with sandstone intercalations and traces of siltstone), was found at depths of $2799 \mathrm{~m}$ in E-1, 2816m in E-1A and $2819 \mathrm{~m}$ in E-1As and had a thickness of 13.5-15 m. The top reservoir was at $2813 \mathrm{~m}, 2831 \mathrm{~m}$ and $2833 \mathrm{~m}$ in the three wells, respectively. The reservoirs had a total maximum thickness of $77.5 \mathrm{~m}$ at E-1As well. They consisted of latest Miocene fan deposits, where sandstone was prevalent (60-70\%) with claystone intercalations (30-40\%) and traces of siltstone. Sandstone was non-consolidated, colourless, translucent transparent, occasionally smoky white, fine to medium, subangular and subrounded, pyritic in part. Claystone was gray, soft to moderated firm, blocky, silty, grading to high siltstone and calcareous to high calcareous in part. Sandstones were cemented and had porosities that varied from 5-20\%. The permeabilities varied from 8-10 md in reservoirs of E-1, to 10-15 md in E-1As. In Fig. 5, a 3-D structure map of Epsilon oil field, contoured at the top of the reservoir is shown. 


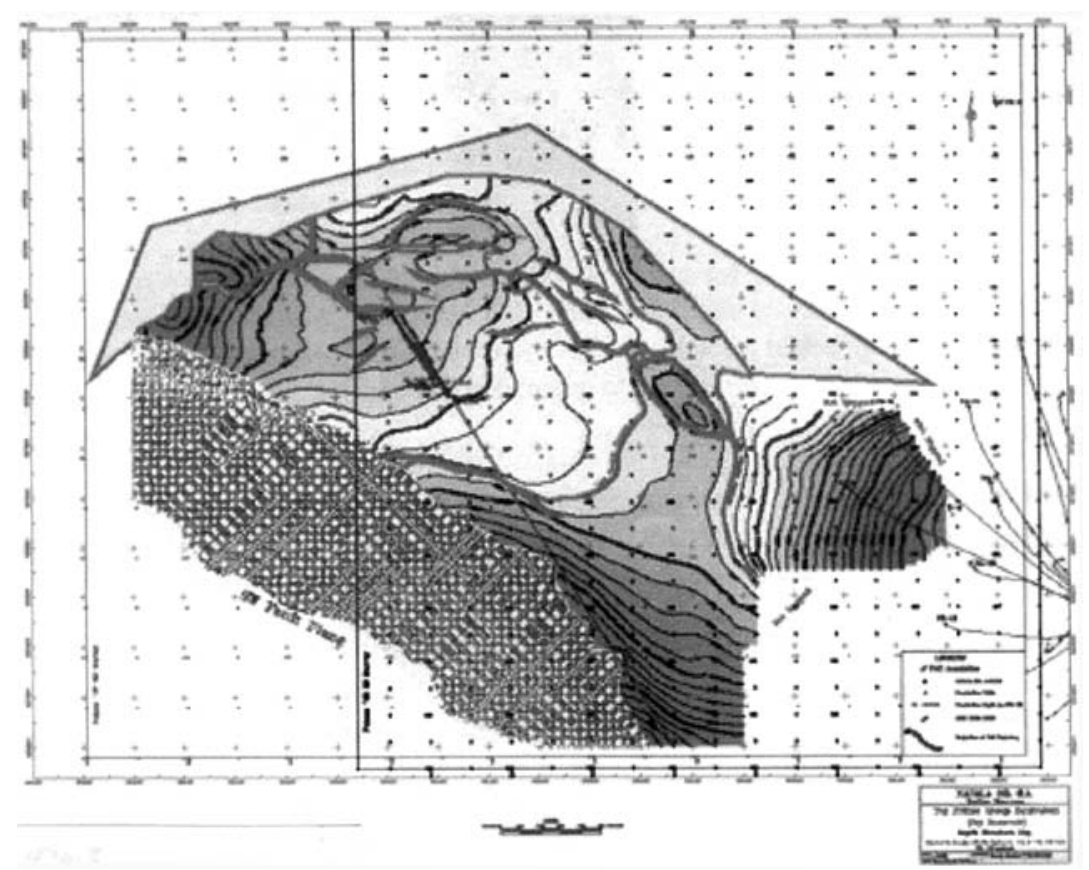

Fig. 5: A 3-D structure map of Epsilon field, contoured at the top of the reservoir.

Epsilon oil is aromatic-asphaltic type with $36.5^{\circ} \mathrm{API}$ at $18^{\circ} \mathrm{C}$ and with sulphur content less than the $4 \%$ of Prinos oil. The average initial pressures for the producing zones were approximately $6000 \mathrm{psi}$. Total reserves at place of Epsilon field were initially estimated to more than $40^{\circ} 10^{6} \mathrm{bbl}$.

\section{Conclusions}

The Prinos basin is the only productive hydrocarbon area in Greece and the Epsilon oil field is the latest field brought to production. Following the general structure of the taphrogenetic basin, it is a dome-like anticline formed by NW-striking and SW-dipping syngenetic faults also related to the trapping mechanism. Guided from the seismic survey of 1993-'97, three drillings took place in 2001' 02 that confirmed the existence of the new hydrocarbon field. The drilling data were in agreement to the geotectonic evolution and depositional model of Prinos basin. The quality and quantity characteristics of initial production led to plans for further drilling operations in Epsilon field.

\section{Acknowledgements}

The authors would like to thank Mr. Costas Papaconstantinou, Managing Director of KAVALA OIL $\mathrm{SA}$, for the permission to publish this work.

\section{References}

Georgakopoulos, A., 1998. Study of source rocks of the petroliferous Prinos-Kavala oil bearing basin using organic geochemical methods. Bull. Geol. Soc. Greece, vol. XXXII, n.3, Proceedings of the $8^{\text {th }}$ International Congress, Patras, May, pp.325-333. (In Greek with English abstract). 
Georgakopoulos, A., 2000. Lithology and stratigraphy of the Neogene Prinos-Kavala basin, Northern Greece. Proceedings R.C.M.N.S. Interim Colloquium, Patras 1998. (Ed.) G.D. Koufos \& Ch.E. Ioakim, Mediterranean Neogene Cyclostratigraphy in marine-continental palaeoenvironments, Geol. Soc. Greece Sp. Publ. No 9, pp.79-84.

Hsu, K.J., 1972. Origin of saline giants: a critical review after the discovery of the Mediterranean evaporite. Earth-Science Review, v. 8, pp.371-396.

Kiomourtzi, P., Pasadakis, N. and A. Zelilidis, 2007. Geochemical Characterization of Satellite Hydrocarbon Formations in Prinos-Kavala Basin (North Greece). Bull. Geol. Soc. Greece, vol. XXXX, n., pp.839-850.

Kiomourtzi, P., Pasadakis, N. and A., Zelilidis, 2008. Source Rock and Depositional Environment Study of the Three Hydrocarbon Fields in Prinos-Kavala Basin (North Aegean). The Open Petroleum Engineering Journal, vol.1, pp.16-30.

Kiomourtzi, P., Zelilidis, A. and N., Pasadakis, 2009. Organic geochemical study of the Kalirahi formation (Prinos-Kavala Basin). $3^{\text {rd }}$ AMIREG International Conference: Assesing the Footprint of Resource Utilization and Hazardous Waste Management, Athens, Greece.

Pollak, W.H., 1979. Structural and lithological development of the Prinos-Kavala basin, sea of Thrace, Greece. Annex Geologique pays Hellenic tome hors serie, fash II, VII ${ }^{\text {th }}$ International Congress on Mediterranean Neogene, Athens, Greece, pp.1003-1011.

Proedrou, P., 1979. The Evaporite formation in the Nestos-Prinos graben in the northern Aegean sea. Ann. Geol. Pays Hellen., Tome hors serie 1979, fasc. II, VII ${ }^{\text {th }}$ International Congress on Mediterranean Neogene, Athens, Greece, pp.1013-1020.

Proedrou, P., 1988. New age determination of the Prinos basin. Bull. Geol. Soc. Greece, vol. XX, n.2, pp.141-147.

Proedrou, P., and T. Sidiropoulos, 1992. Prinos field - Greece, Aegean basin, structural traps. Treatise of petroleum Geology atlas of oil and gas fields, AAPG, pp.275-291.

Proedrou, P., 2001. South Kavala gas field-Taphrogenetic Prinos basin. Bull. Geol. Soc. Greece, vol. XXXIV, n.3, pp.1221-1228.

Proedrou, P., and C.M., Papaconstantinou, 2004. Prinos basin - A model for oil exploration. Bull. Geol. Soc. Greece, vol. XXXVI, n.1, pp.327-333.

Walker, R.G., and E. Mutti, 1973. Turbidite facies and facies associations, in G.V. Middleton and A.H. Bouma, eds, Turbidites and deep water sedimentation: SEPM Pacific Section Short Course, Anaheim, California, pp.119-157. 